The Geneva Papers on Risk and Insurance, 18 (No. 67, April 1993), 158-173

\title{
Price Regulation in US Automobile Insurance A Case Study of Massachusetts Private Passenger Automobile Insurance 1978-1990*
}

\author{
by Richard A. Derrig, Ph.D.**
}

\begin{abstract}
This short note highlights price regulation in the United States Personal Automobile Market by reviewing the results of the most highly-regulated U.S. market, the fix-andestablish system in Massachusetts during 1978 to 1990. Financial outcomes of the state-run market are shown. Effects of pricing policy on the size of the residual market, interclass subsidies and the participation of national property-casualty companies in the Massachusetts market are discussed. Contrasts with the post-proposition 103 California personal auto market are explored. Implications for guaranty funds are derived. Finally, the outlook for the Massachusetts and California personal auto markets is discussed together with implications for the upcoming integration of the EEC insurance markets.
\end{abstract}

\section{Introduction}

Regulation in Massachusetts stands alone among all other state regulatory systems for private passenger (personal) automobile insurance. While all other state systems accommodate various levels of competition among insurance companies, the Commonwealth of Massachusetts, through an insurance commissioner, controls all aspects of the sale and delivery of services under the personal automobile insurance policy.

This review will concentrate on price regulation under the Massachusetts fix-and-establish rating system. Under that system, created and continually modified by the Legislature,$^{1}$ the Commissioner of Insurance has direct control over all aspects of rating plans, voluntary and residual market mechanisms, claims handling procedures and, most importantly, prices for the insurance product. A bricf experiment with competitive rating in 1977

\footnotetext{
* This paper is based upon a lecture given June 4, 1991 at the Seminar Für Bank- und Versicherungsbetriebslehre, Universität Hamburg, Germany. Special thanks are due to Professor Walter Karten for providing a German translation.

** Senior Vice President, Automobile Insurers Bureau of Massachusetts, Boston, Massachusetts, 02110 .

1 During 1990 the Massachusetts legislature passed 14 new statutory provisions for auto insurance. The topic of the new legislation ranged from the number of years of experience to be considered for the Safe Driver Plan to the establishment of an Insurance Fraud Bureau.
} 
proved to be a disaster as companies began to charge cost-based rates, rates that were substantially higher than the prior 1976 state-made rates for certain previously-underpriced risk classes. This paper concentrates on the results of 1978-1990, results obtained under the 1977 legislated authorization to return to state-made fix-and-establish ratemaking.

We begin with the stated objectives and standards of price regulation. After a description of the Massachusetts personal auto regulatory system, and its dismal results since 1978, two other key areas, the residual market and interclass subsidies, are examined. As total surplus losses crossed the $\$ 1$ billion level in 1987 , major U.S. auto writers withdrew from the market resulting in a greatly decreased capital base. The implications of those withdrawals are discussed.

Looking toward regulatory systems in other states, we compare Massachusetts and California under the latter's voter-initiated Proposition 103 rules. Specifically, we assess the likelihood of price regulatory action in California which may lead to the Massachusettstype results. The resulting outlook for guaranty funds is explored briefly.

A final section offers the prospects for the future of personal auto insurance in Massachusetts and the implications for the European EEC insurance systems.

\section{The objectives of price regulation}

The regulation of rates (prices) for motor vehicle insurance in Massachusetts is governed by a state law, chapter $175 \mathrm{E}$, passed in August, 1976. The standards applicable to the making and use of rates are similar to those promulgated in other states. They include, but are not limited to,

(a) Rates shall not be excessive or inadequate, as herein defined, nor shall they be unfairly discriminatory, and

(b) Consideration shall be given, to the extent applicable, to past and prospective loss experience within and outside the commonwealth, to catastrophe hazards, to a reasonable rate of return on capital after provision for investment income, to past and prospective expenses both country-wide and those specially applicable to the commonwealth, and to all other factors, including judgment factors, deemed relevant within and outside the commonwealth.

The objectives of this type of regulatory standard are two-fold. First, a standard such as the one defined in (a) above provides protection to the consuming public from unfair pricing schemes. Under that protection, a personal automobile market should always be made available by private insurance carriers, either stockholder-owned or mutual associations of policyholders, under rating plans and prices that are "fair". "Fair", however, is in actuality left undefined and in the hands of a single governmental agent, the Commissioner of Insurance, subject only to legislative mandates and ultimate review by the Supreme Judicial Court of the Commonwealth of Massachusetts. ${ }^{2}$

Second, the standard in (b) is designed to provide for the overall parameters of the ratemaking system. Most importantly, this statement contains insurance carrier protections

\footnotetext{
${ }^{2}$ In theory, statutes and regulatory schemes could be reviewed by the U.S. Supreme Court but that would be a rare occurrence. Review by the Massachusetts SJC, however, is not rare, having occurred five times during the 1980's.
} 
against unfair state-imposed prices that do not provide for a "reasonable rate of return on capital". Without the expectation of such a return, private enterprise companies will not commit their capital, or will be forced into insolvency as their capital is depleted, or both. The allowance of the expectation of reasonable profits to insurance companies bolsters the solvency prospects and, thereby, the protection to consumers that their company will be able to pay contracted claims once they occur. An analogy with another sector of the U.S. economy may help.

One can see how, prior to deregulation, the U.S. airline industry regulators protected the consumers from unfair prices by regulating tariffs not by supply and demand but by regulatory "fair" schemes. Airline carriers themselves were protected through regulated rates (high enough to keep inefficient carriers in business to "serve" the markets). These ideal supply and demand protection standards are common to schemes which are designed to allocate assets by "reasonable" rules and regulations rather than by the invisible hand of the marketplace. With the demise of the central planning ethic of Eastern European economies, we may now appreciate how difficult, inexact, and counterproductive the operation of bureaucratic approximations to such complex markets turns out to be.

\section{Fix and establish in Massachusetts personal automobile insurance}

Under the current statutory scheme, the Commissioner of Insurance is obligated to hold a public hearing annually in order to decide if competitive rating should be allowable for personal auto insurance. Each year since 1978, the Commissioner has decided that the environment for competitive rating is not quite ready yet. ${ }^{3}$ With that decision, the Commissioner then sets in motion a process (fix-and-establish) which determines in minute detail, how and at what price for the coming year each of the 3.3 million Massachusetts automobiles will be rated for bodily injury and property damage liability (compulsory at low fixed levels of coverage) and for physical damage (optional but with $\$ 500$ deductible coverage being the standard). In addition to setting new prices to be effective on January 1 , the commissioner separately examines insurance company profits, cost containment measures (especially against fraudulent claims), groupings of towns into rating territories, a safe driver (bonus/malus) plan and a host of other operational items. Two of the more extreme examples will illustrate how intensive the operational regulation has been. One year, the Commissioner determined that all drivers would be asked on their applications for insurance whether or not they smoked. Presumably, this might lead to the creation of a non-smoking discount, not for life insurance, but for automobile insurance! This year, the Commissioner must designate which vehicles are "high-theft" and, therefore, are subject to high-risk rating in the absence of the proper anti-theft devices. The regulatory scheme in place necessitates that, in some cases, two models that are similar in all respects except one ("turbo" is one example, number of engine cylinders is another) may be designated half high-theft and half not. While the overall objective may be laudable, this kind of microscopic management is best left to the marketplace, not the bureaucrats.

The heart of the fix-and-establish scheme is the public hearing on the so-called main rate case. Recommendations are made by the Automobile Insurers Bureau ("AIB") on behalf of all insurers. Adversarial opposition is provided by the State Rating Bureau

\footnotetext{
3 Competitive rating has been allowed since 1981 for commercial automobile insurance.
} 
("SRB"), an arm of the Division of Insurance, and the Attorney General ("AG") under his consumer protection responsibilities. Each of the parties have access to all premium and claim payment data reported by all companies under the Commissioner's statistical reporting plan. Independent actuarial analyses provide for a range of recommendations. After allowing for the cross-examination of each parties' expert witnesses, the Commissioner reviews all available evidence and decides upon new rates to be effective January 1. Those rates must be charged by each company, independent of the service levels they provide. ${ }^{4}$ One year, the public hearing process took a record 87 days of expert testimony resulting in a delay in the rate decision until May of the year for which the rates were to be in effect. That 1987 decision was appealed to the Supreme Court by the AIB and was remanded to the Commissioner for even further consideration. The next section provides a retrospective look at how these ratemaking decisions have fared since 1978.

\section{Financial result 1978-1990}

From the insurance company point of view, the key to a healthy insurance market is the long-run prospects for reasonable profits commensurate with the risks to their invested capital. Companies undertake financial risk by their choice of investments for their financial assets (stocks, bonds-junk or otherwise, real estate and other investments) and their choice of underwriting various lines of insurance. In the United States, investments are primarily in domestic capital markets and in relatively safe financial investments. ${ }^{5}$ The underwriting risk, however, is somewhat controllable by choosing market penetrations by line and by state. The underwriting results we see below did not offer expected rewards commensurate with the expected risks.

Chart 1 shows the Earned Premium, Incurred Losses and Expenses and, therefore, the underwriting results for each policy year from 1978 to 1989. During that time, annual earned premium rose from $\$ 700$ million to $\$ 2.1$ billion. At the same time, losses and expenses rose from $\$ 720$ million, for a $2.5 \%$ underwriting loss in 1978 , to $\$ 2.5$ billion in 1989 for an underwriting loss of $15.1 \%$. The thirteen year average underwriting loss, as shown in Chart 2 , was $11.5 \%$ of premium. Was this a reasonable return for the risk involved?

Massachusetts, unlike most other states, ${ }^{6}$ has provided since 1976 for the setting of target underwriting losses within the rates based upon explicit models derived from formal financial economic principles, especially, the Capital Asset Pricing Model ("CAPM"). Details on the process can be found in Derrig (1987) and Derrig (1990). Each of those explicitly derived target underwriting returns were set after taking investment income into account. Those targets are shown in Chart 2 . They range from a barely positive $+0.2 \%$ in 1978 to a low of $-8.0 \%$ in 1987 ; overall they average $-4.6 \%$ for the thirteen year period. Column (D) of Chart 2 shows the year-by-year shortfall of the actual results from the expected targets. Disastrous results in the 1985 and 1986 rates led the way to an average annual shortfall of nearly $7 \%(6.9 \%)$ of premium for the thirteen year period. The same

4 There is a small, but fairly inactive market for reduced-rate group marketed plans.

${ }^{5}$ With the current Executive Life Insurance Company seizures in California and New York by the insurance commissioners of those states and the California takeover of First Capital Life, the veneer of safe investments may turn out to be dangerously thin.

6 California is becoming more Massachusetts-like with its Proposition 103 rate-of-return hearings in 1990 and 1991. 


\section{Chart 1}

Massachusetts private passenger automobile insurance underwriting results 1978 through 1989

All coverages

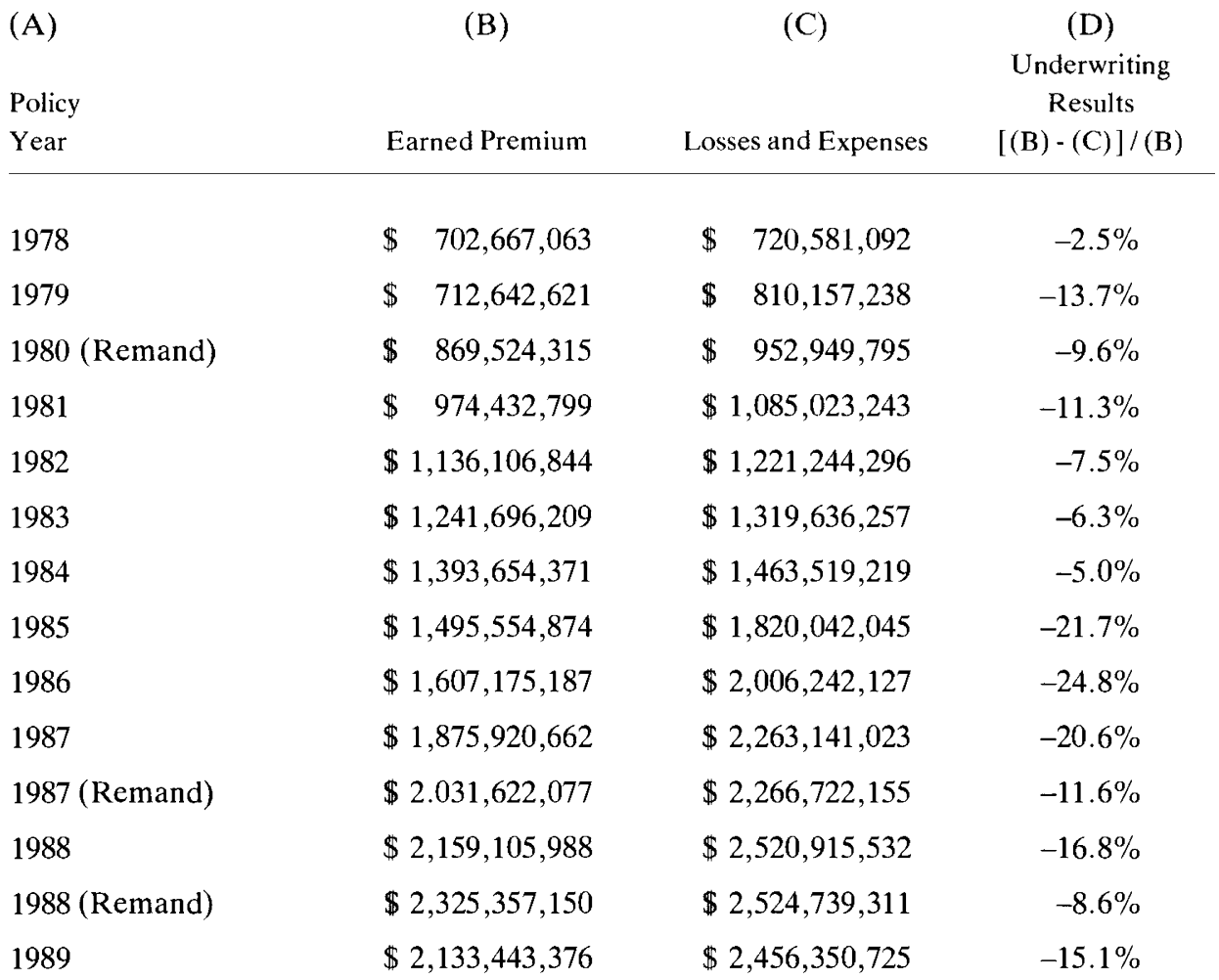

Source:

Automobile Insurers Bureau of Massachusetts Underwriting Results. 


\section{Chart 2}

Massachusetts private passenger automobile insurance Comparison of target underwriting profits with actual underwriting results

All coverages

\begin{tabular}{|c|c|c|c|}
\hline (A) & $\begin{array}{c}\text { (B) } \\
\text { Target }\end{array}$ & $\begin{array}{c}\text { (C) } \\
\text { Actual }\end{array}$ & (D) \\
\hline Policy & Underwriting & Underwriting & Shortfall \\
\hline Year & Profit ${ }^{*}$ & Results & (C) - (B) \\
\hline 1978 & $0.2 \%$ & $-2.5 \%$ & $-2.7 \%$ \\
\hline 1979 & $-2.2 \%$ & $-13.7 \%$ & $-11.5 \%$ \\
\hline 1980 (Remand) & $-1.5 \%$ & $-9.6 \%$ & $-8.1 \%$ \\
\hline 1981 & $-1.9 \%$ & $-11.3 \%$ & $-9.4 \%$ \\
\hline 1982 & $-2.4 \%$ & $-7.5 \%$ & $-5.1 \%$ \\
\hline 1983 & $-7.6 \%$ & $-6.3 \%$ & $1.3 \%$ \\
\hline 1984 & $-5.4 \%$ & $-5.0 \%$ & $0.4 \%$ \\
\hline 1985 & $-7.2 \%$ & $-21.7 \%$ & $-14.5 \%$ \\
\hline 1986 & $-5.5 \%$ & $-24.8 \%$ & $-19.3 \%$ \\
\hline 1987 & $-8.0 \%$ & $-20.6 \%$ & $-12.6 \%$ \\
\hline 1987 (Remand) & $-8.0 \%$ & $-11.6 \%$ & $-3.6 \%$ \\
\hline 1988 & $-6.6 \%$ & $-16.8 \%$ & $-10.2 \%$ \\
\hline 1988 (Remand) & $-6.6 \%$ & $-8.6 \%$ & $-2.0 \%$ \\
\hline 1989 & $-6.9 \%$ & $-15.1 \%$ & $-8.2 \%$ \\
\hline $\begin{array}{l}\text { Average since } 1978 \\
\text { with } 1987 \text { and } 88 \text { Remands }\end{array}$ & $-4.6 \%$ & $-11.5 \%$ & $-6.9 \%$ \\
\hline
\end{tabular}

Source:

Automobile Insurers Bureau of Massachusetts Underwriting Results.

${ }^{*}$ Decision profit provisions weighted by earned premium by coverage. 


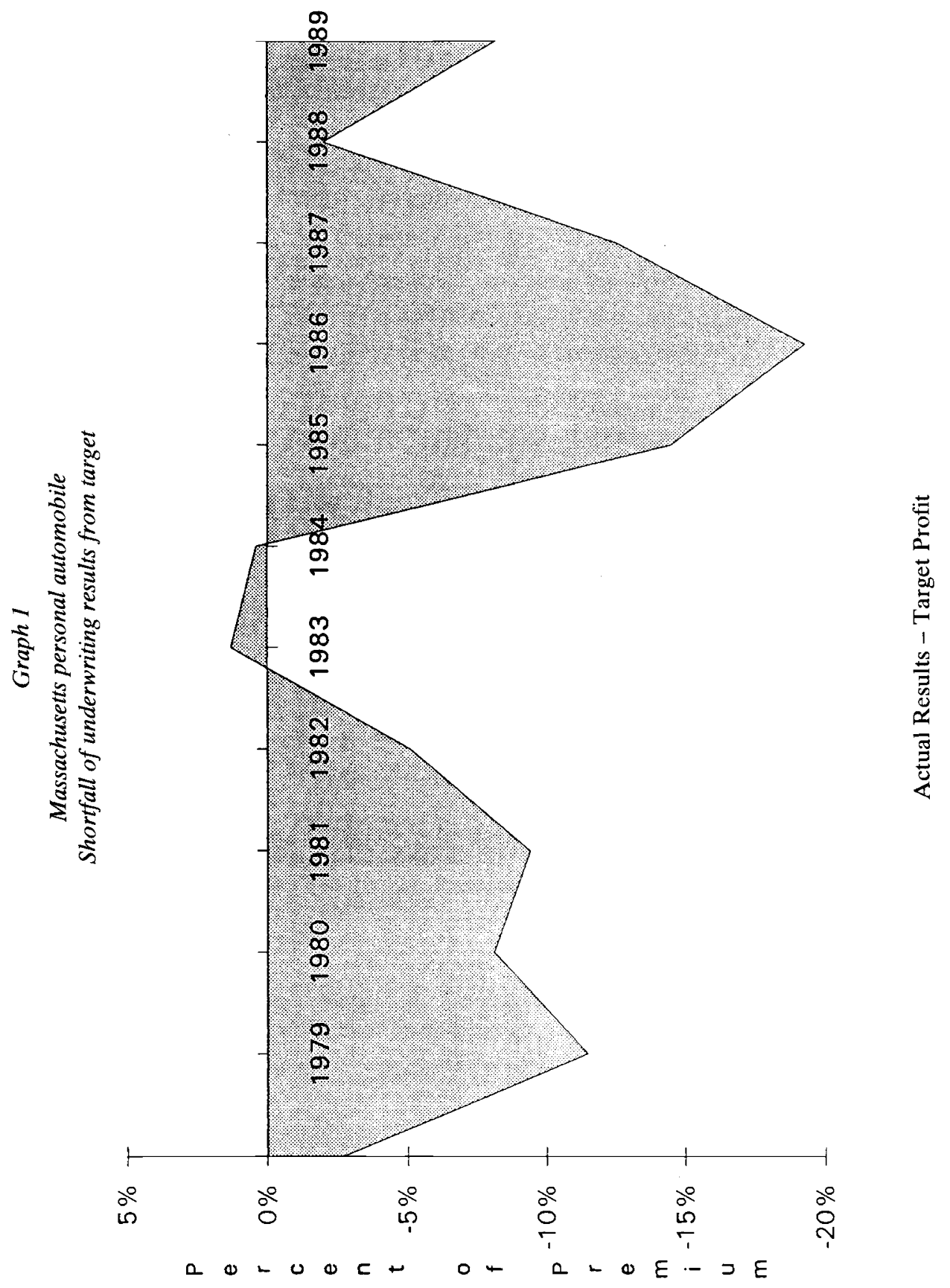


results are shown graphically in Graph 1 . These overall shortfalls amount to about $\$ 1.5$ billion. If the single set of rates fixed and established by the commissioner were charged by a single company for the entire Massachusetts market, that company would have been insolvent by 1987 .

Incredibly, results would have been worse were it not for court-ordered remand decisions (the commissioner erred in setting the rates and he must correct those errors) in 1980, 1987 and 1988. In each of the latter two years, premiums were increased retroactively by 8 to $9 \%$ to account for inadequate loss (claim payment) provisions in the original rates and to provide about $\$ 325$ million more for the "fair" premium.

In hindsight, it is clear why those shortfalls occurred. Chart 3 shows that the adversarial parties, those not connected to actual operation of insurance companies, advocated loss provisions in rates that averaged a $14 \%$ underprediction annually. While it is difficult to forecast future claim payments, thirteen consecutive years of massive underpredictions lead only to one conclusion: biased rate - suppressing actuarial analyses, most of which were adopted by the commissioner.

\section{Chart 3}

Massachusetts personal automobile

Loss cost prediction errors

$1978-1990$

\begin{tabular}{lcc} 
& $\begin{array}{c}\text { Average } \\
\text { error }\end{array}$ & $\begin{array}{c}\text { Average } \\
\text { absolute } \\
\text { error }\end{array}$ \\
\hline Auto Insurers Bureau & $-3 \%$ & $7 \%$ \\
Attorney General $^{*}$ & $-14 \%$ & $14 \%$ \\
Decision & $-11 \%$ & $11 \%$ \\
State Rating Bureau & $-14 \%$ & $14 \%$ \\
$* 1980-1990$ only & & \\
\hline
\end{tabular}

Graph 2 shows clearly how the loss provisions in the rates lagged actual costs for each and every year. It shows too how the court-ordered remand decisions helped close-thegap. Finally, Graph 2 shows that the underestimation seems to have reoccurred in 1989 and 1990. Note that the total amount of underestimation over those years amounted to $\$ 1.3$ billion. What are the consequences of such poor regulatory action on setting prices?

\section{Interclass subsidies and the residual market}

As part of the main rate case decision each year, the commissioner determines how the average rate will be spread among all risks according to a classification plan. In Massachusetts, drivers are classified by the town in which their car is garaged (territorial rating) and by certain characteristics of the drivers themselves. Driving classes include: 


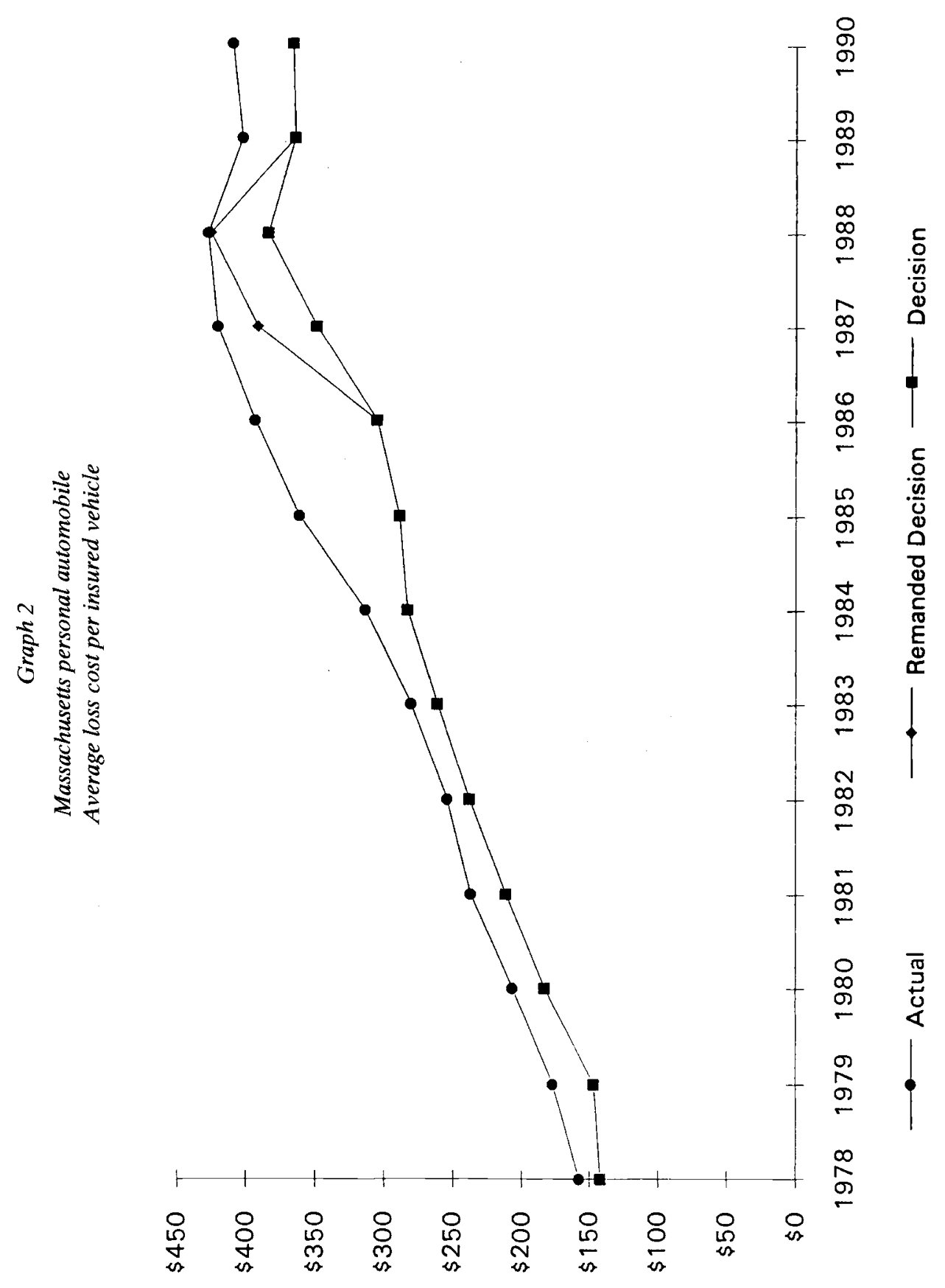


Class 10

Adult Drivers

Class 15:

Senior Citizens (over 65 years of age)

Class 17:

Inexperienced Principal Driver, licensed 4-6 years

Class 18:

Inexperienced Occasional Driver, licensed 4-6 years

Class 20, 25:

Inexperienced Principal Driver, licensed $0-3$ years

Class 21, 26:

Class 30:

Inexperienced Occasional Driver, licensed $0-3$ years

Business Use

In every year since 1978, rates for the higher-rated classes of drivers, and for territories containing the urban centers of Massachusetts such as Boston and Lawrence, have been deliberately set below what the reported claim data would determine as the fair premium charge. Large subsidies have been provided to the inexperienced drivers, and urban drivers, at a small per-car expense to the adult, and rural classes. For example, in 1991 rates, we have the following overcharges $(-)$ and undercharges $(+)$ for some of the classifications.

\begin{tabular}{lcc} 
Class & $\begin{array}{c}\text { Percent } \\
\text { of Market }\end{array}$ & Subsidy \\
\hline 10 & $74 \%$ & $-\$ 32.58$ \\
17 & $4 \%$ & $+\$ 122.25$ \\
20 & $1 \%$ & $+\$ 637.37$ \\
30 & $1 \%$ & $-\$ 37.01$ \\
Territory & & \\
1 Rural & $4 \%$ & $-\$ 71.76$ \\
14 Urban & $4 \%$ & $+\$ 573.06$ \\
26 Urban & $0.4 \%$ & $+\$ 250.18$ \\
\hline
\end{tabular}

In theory, since the rates are balanced by the commissioner for the subsidies (just as much subsidy is collected as is given away), there should be no overall effect on rate adequacy or profit shortfalls. There is an effect, however, on the size of the residual market, i.e., the number of policies that companies will not write voluntarily and will only pay a share of the underwriting losses. We discuss this effect next.

The rate subsidies, combined with the large underwriting shortfalls, have led companies to write larger and larger proportions of the market as risks ceded to the residual market mechanism. Currently, that mechanism is a joint underwriting association called Commonwealth Automobile Reinsurers ("CAR"). The results are dramatically portrayed by the increasing size of the residual market over the period 1977-1990.

This enormous growth in the residual market provides for inter-company strains over how to share equitably the large deficit expected to be produced in that market. All the above problems have led major national U.S. companies to withdraw from the Massachusetts personal auto line. 


$\begin{array}{cc}\text { Year } & \begin{array}{c}\text { Residual \% of } \\ \text { the market }\end{array} \\ 1977 & 23 \% \\ 1978 & 30 \% \\ 1979 & 36 \% \\ 1980 & 40 \% \\ 1981 & 46 \% \\ 1982 & 47 \% \\ 1983 & 47 \% \\ 1984 & 46 \% \\ 1985 & 48 \% \\ 1986 & 53 \% \\ 1987 & 57 \% \\ 1988 & 63 \% \\ 1989 & 67 \% \\ 1990 & 55 \%\end{array}$

\section{National company withdrawals}

The sequence of underwriting profit shortfalls, and subsequent residual market population increases, were recognized by the AIB in the mid-1980s and formally reported to the commissioner in each annual rate filing. Once recognized, one would think corrective action should be taken to insure more accurate loss cost forecasts would be used. That would be the logical step undertaken by an unbiased regulator. That, obviously, did not happen in Massachusetts.

Bias in loss cost forecasting need not be a pejorative term. Statisticians and actuaries have lived with bias (expected value of the errors not equal to zero) for many years. In fact, when the National Association of Insurance ("NAIC") reviewed the entire fair rate of profitability issue in 1983, they recognized that fair rate of return formulae depend upon unbiased forecasting methods. If bias is observed, steps must be taken to remove that bias. Chart 4 contains the full NAIC text.

It is quite understandable then that major U.S. companies would come to the conclusion that the overly-regulated Massachusetts Personal Auto line of insurance would continue to be unprofitable for the foreseeable future. Indeed, a full $32 \%$ of the market has discontinued writing personal auto. Leading insurers such as Allstate, Kemper, CIGNA, Fireman's Fund and Royal Insurance have all given up their Massachusetts personal auto business. It is now joked that Allstate should change its name to "Moststates" because it no longer does business in Massachusetts. Chart 5 provides the full list of withdrawing companies as of November 1, 1991.

In the long run, the consuming public are the ones whose services are diminished by the withdrawals. National company research and innovation, together with large supporting capital bases, are lost with national company withdrawals. Replacement of national writers with local companies may temporarily fill the void, but only at the risk that their much smaller capital base may not prove sufficient in times of adverse investments, underwriting or catastrophes. 


\section{Chart 4}

\section{EXCERPT}

1983 Investment income task force report of the National Association of Insurance Commissioners*

"Further, it is assumed that a rate filing uses an unbiased estimate of the expected value of losses and expenses. The fact that actual losses will vary around the predicted value is an inherent feature of the insurance business. Such uncertainity should be taken into account either explicitly or implicitly when choosing a fair target rate of return for insurers. If the estimate of losses and expenses is a priori biased one way or another, the method used to estimate losses and expenses should be changed to remove that bias."

* The report is reprinted in the Journal of Insurance Regulation, September 1984, pp. 39-112; and December 1984, pp. 152-181.

\section{Chart 5}

Companies withdrawing from personal auto insurance in Massachusetts

- Allstate Insurance Companies

- American Mutual Group (insolvent)

- American Universal Insurance Company (insolvent)

- Central Mutual Insurance Companies

- Chubb Group of Insurance Companies

- Cigna Corporation

- Continental Insurance Companies

- Crum and Forster Insurance Companies

- Firemans Fund Insurance Companies

- General Accident Group

- General Motors Insurance Group
- Hartford Insurance Group

- Home Insurance Group

- Kemper Group

- Peerless Insurance Group

- Reliance Insurance Group

- Royal Insurance

- St. Paul Insurance Companies

- Shelby Insurance Companies

- U S F \& G

- Utica National

These companies represent $32 \%$ of the market.

If one includes Aetna, which has not filed a petition to withdraw pursuant to CAR Rule 11 B.3, but which has stated in a complaint filed in U.S. district Court that it has "determined" to withdraw from the market, these companies represent $41 \%$ of the market. 


\section{The post-proposition 103 California market}

According to the May 14, 1991 Wall Street Journal, "California's quest for cheaper auto insurance has become a three-ring political circus". Now in their second year of public hearings on "fair" rates of return, California consumers and insurance companies alike are completely uncertain about their future form of regulation, much less about the outcomes of those new regulations. How this untenable situation came to pass was described in Derrig (1990) and is summarized here for background information.

On November 8, 1988, California voters approved a ballot initiative known as Proposition 103 which, among other things, mandated a rollback in rates for automobile insurance and some other lines to a level $20 \%$ below the level existing one year earlier, November 8,1987 . The ballot initiative also provided for a one year rate freeze unless the insurer was "substantially threatened with insolvency". Subsequent to the one year period, rates could be changed only under a prior approval system with a key change in the criterion for approval.

This setting of financial policy and prices by popular vote violated the insurers rights to due process under the State and Federal Constitutions. Such a decision was handed down on May 4, 1989 by the California Supreme Court (CALFARM INS. CO. v. Deukmejian 258 Cal. Rept. 161 [Cal 1989]) which found that the "Insolvency Standard" was unconstitutional on its face. While the rollback (to 1987) and reduction (20\%) were not invalid per se, they were subject to the right of the insurer to demonstrate a particular rate was confiscatory. The Court said it was not concerned with the way rates were set but with whether the result was confiscatory, i.e., not fair and reasonable. The Court reaffirmed that the capital attraction standard of the Hope Decision ${ }^{7}$ would stand for the purpose of determining a fair and reasonable opportunity for a return on invested capital commensurate with the risk of the enterprise. In discarding the year-long rate freeze the Court said that, considering the difference between rates which may be the result of current competition (de facto fair) and rates mandated to be $20 \%$ below a prior rate level, insurers must be given "an adequate method for obtaining individual relief" from rates which are confiscatory.

The two events of the voter approval of Proposition 103 and the subsequent Court Decision have created a regulatory review of individual by-line-by company rates unprecedented in U.S. regulatory history. Prior to Proposition 103, the rate statute prohibited inadequate, excessive or unfairly discriminatory rates, but said that a rate in a competitive market could not be held excessive. This latter provision provided for the fiercely competitive California Auto Insurance market prior to the ballot initiative. ${ }^{8}$ Under Proposition 103 (1861.05(a)) the standard for rate review is "(n)o rate shall be approved or remain in effect which is excessive, inadequate, or unfairly discriminatory. In considering whether a rate is excessive, inadequate or unfairly discriminatory no consideration shall be given to the degree of competition and the commissioner shall consider whether the rate mathematically reflects the insurance company's investment income". Finally, the Court

${ }^{7}$ Federal Power Commission v. Hope Natural Gas Company, 320 U.S. 591 (1944).

${ }^{8}$ California Department of Insurance figures released in a press conference on August 1, 1989 showed that during 1987 auto insurers lost about $2.7 \%$ of premium after the consideration of investment income. 
admonished, and the Department of Insurance picked up as a standard for review, "(O)ver the long term the state must permit insurers a fair return...", the same standard as in Massachusetts (Section 2 above).

For more than two years, regulations have been promulgated, rescinded, and promulgated again to provide for the voter-ordered $20 \%$ rollback on 1989 policies within the court-ordered guidelines. An early set of regulations set June 3, 1989 as a deadline to file for a review of rates from the rollback period.

The experience has been nothing short of regulatory paralysis. More than 4,000 exemptions to the $20 \%$ rollback had been filed by over 600 insurers under the CALFARM standard by June, 1989. By August, 1991, administrative hearings had been held on only two company rollback applications and none has been the subject of final administrative action. Only three prior-approval applications have been ruled on after administrative hearings. ${ }^{9}$ After the subsequent election of an insurance commissioner, as required by Proposition 103, yet another regulatory scheme emerged in $1991 .{ }^{10}$ Amid declarations that $\$ 2.5$ billion would be returned through rollbacks of 1989 rates under the 1991 Commissioner Garamendi regulation, still more court challenges were filed by major insurers such as Fireman's Fund, USF\&G and SAFECO. ${ }^{11}$ According to the October 17, 1991 Wall Street Journal, eight large insurers would have to return more than $\$ 100$ million each. Even one smaller insurer, Mercury Casualty Company, would be required to return $\$ 65$ million, an amount equal to about $40 \%$ of their 1990 policyholder surplus. One commonality among the California regulations is an attempt to artificially suppress the allowed rate of return to the $10 \%-11 \%$ range.

The reality of the situation in California since prop 103 was to increase rates, as the market would dictate, rather than decrease the rates as the voters would have preferred. Californians must confront the direct cost-price link if they wish market-supported rates. Cost-cutting measures such as no-fault insurance under a verbal tort threshold, are essential to lower rates. Manipulation by state regulators of the prior approval system to suppress rates will eventually lead to market problems similar to the ones reported above for Massachusetts (see Harrington, 1992). While the outcome is in doubt, regulators continue to grapple with the same problems that plagued Massachusetts during the 1970's and 1980's. It is hoped here that the Massachusetts financial results (Section 3) will not be repeated.

\section{Implication for guaranty funds}

The kind of erosion of financial assets caused by inadequate prices, and the subsequent withdrawal of 30 to $40 \%$ of the insurers' capital supporting the Massachusetts market, does not bode well for policyholder guarantees of claim payments. In Massachusetts, similar to many other states, the guaranty fund is of the "post-assessment" type. Once an insolvency occurs, and two large companies, American Mutual and American

${ }^{9}$ California Department of Insurance, Adoption of Emergency Regulations, File No. ER-19a, pages 5-6.

${ }^{10}$ California Department of Insurance, Regulations for Review of Rates, File No. ER-19a, August 13, 1991.

${ }^{11}$ Best's Insurance Management Reports, September 9, 1991. 
Universal, writing Massachusetts personal auto policies became insolvent since 1988, all other companies pay the insolvent companies claims up to a fairly large per claim limit. Companies are then entitled to recover those payments in future premiums.

Clearly, whenever large national companies such as CIGNA and Kemper refuse to allow their capital to support regular business, that capital is also not available to weather insolvencies. Should California regulators force insurers to adopt inadequate rates, such as occurred in Massachusetts during 1978-1989, or withdraw from the market, an insolvency crisis could occur in the largest U.S. auto insurance market. Given the recent Savings and Loan banking failures, no one is anxious to repeat that type of burden on the economy. One major difference with the banking crisis is that individual states, not the federal government, will be responsible for cleaning up each insolvency mess.

\section{The outlook for the future}

The Massachusetts personal auto insurance market is beginning to experience a turnaround after the long decline outlined above. For 1990 calendar year, Massachusetts private passenger automobile underwriting results (76\% Loss Ratio) are now more or less in line with total U.S. market results of $74 \%$. Likewise, the decline in the population of the residual market CAR from $67 \%$ in 1989 to $55 \%$ in 1990 bodes well for a turnaround. Unfortunately, the total U.S. market is not yet viewed as profitable and the meticulously calculated Massachusetts underwriting target loss ratios are still not being met.

In early 1991, the Commissioner of Insurance ruled in her annual "competition" hearing that competitive rating should be considered again as the preferred form of regulation. She ruled that ways should be found for a smooth transition to such a market. As of this writing, no such transition has been implemented. Finally, Fireman's Fund, the first company to exit the state in 1987, has announced an interest in returning to Massachusetts. Left unstated was the amount of interest they will show in the personal auto line of insurance.

The outlook for California, however, is much bleaker. Their regulator shows little in the way of signs that he will permit pricing to provide for a fair rate of return. "Generic" hearings on ways to measure and justify profits seem to be resuming after a short lapse. Only in the cost containment area does the California Commissioner align himself with insurance companies to press for cost reductions in terms of no-fault insurance alternatives.

What might all this experience mean for the upcoming European Economic Community ("EEC") integration of insurance systems? What could be the effect on the German system? I am willing to suggest two lessons are in order. First, the closer one can get to a competitive market with little price regulation, but with forceful solvency regulation, the better. Solvency has always been a high priority of European (and German) concern. That need not change. Indeed three international conferences of insurance, finance and economic issues have been held since 1986 in order to increase the understanding by technical experts of the interrelations among pricing, capital commitments and solvency. Proceedings of the first two of those conferences have been published to date (see Cummins and Derrig 1988, 1989 and 1991). The stimulation of capital efficiency and innovation through pricing deregulation is, however, a worthy goal. All too often European insurance actuaries have built pricing models which are pure supply-side models. Those models have been implemented by EEC governments, but like the pre-Proposition 103 California market, tend to ignore real consumer demand. They ignore consumer demand, however, at their own peril. 


\section{REFERENCES}

DERRIG, Richard A. (1987), "The Use of Investment Income in Massachusetts Private Passenger Automobile and Workers' Compensation Ratemaking", in Fair Rate of Return in PropertyLiability Insurance, ed. J. David Cummins and Scott E. Harrington, Kluwer-Nihoff Publishing, Boston.

DERRIG, Richard A. (1990), "The Development of Property-Liability Insurance Pricing Models in the United States 1969-1989”, lst AFIR International Colloquium of The International Actuarial Association, Paris.

CUMMINS, J. David, and DERRIG, Richard A., eds., (1988), Classical Insurance Solvency Theory, Kluwer Academic Publishers, Boston.

CUMMINS, J. David, and DERRIG, Richard A., eds., (1989), Financial Models of Insurance Solvency, Kluwer Academic Publishers, Boston. Reviewed Scand. Actuarial J. 1989: 123-127.

CUMMINS, J. David, and DERRIG, Richard A., eds., (1991), Managing The Insolvency Risk of Insurance Companies, Kluwer Academic Publishers, Boston.

HARRINGTON, Scott E. (1992), "Rate Suppression”, Journal of Risk and Insurance, 59: 185-202. 